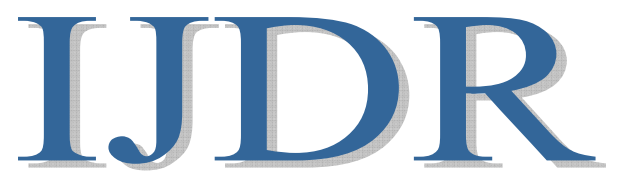

International Journal of Development Research

Vol. 10, Issue, 06, pp. 36970-36973, June, 2020

https://doi.org/10.37118/ijdr.19163.06.2020

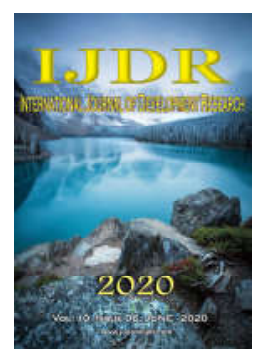

\title{
PATHOLOGICAL USE OF THE INTERNET CAUSING SOCIAL ANXIETY
}

\section{${ }^{1}$ Royler Anderson Said Ferreira, ${ }^{1}$ Bruno Pereira Gonçalves, ${ }^{1}$ Aline Mary Moreira de Melo, ${ }^{1}$ Jean Mark Lobo de Oliveira and ${ }^{* 2}$ David Barbosa de Alencar}

\author{
${ }^{1}$ Academic department, University Center FAMETRO, Amazon-Brazil \\ 2Institute of Technology and Education Galileo of Amazon (ITEGAM), Brazil
}

\section{ARTICLE INFO}

\section{Article History:}

Received $08^{\text {th }}$ March, 2020

Received in revised form

$17^{\text {th }}$ April, 2020

Accepted $21^{\text {st }}$ May, 2020

Published online $29^{\text {th }}$ June, 2020

\section{Key Words:}

Chatbot; Mobile devices.

*Corresponding author:

David Barbosa de Alencar,

\begin{abstract}
The pathological use of the internet (PUI) interferes in a person's social life based on self-reports that declare themselves "addicted" or "dependent" on the internet. This is a bibliographic research to understand the concepts applied at work, adopting quantitative research through a questionnaire to a random audience and descriptive research with support in matters, where they report subjects such as Social Anxiety, Pathology and the Use of the Internet. With the exposed, the main reason in relation to the abusive use of the internet, is used for communication, for satisfactory or sexual purposes and surf in a general context. In short, the technology that helps in communication, research and several other benefits, when elevated to overuse, brings psychological problems. It was possible to avaluate before society with the application of the questionnaire, that the internet is not harmful, as the subject ends up facing fragile situations, when the person is in a depressed state in the face of personal disorders, among others, they found a cure on the internet for their problems.
\end{abstract}

Copyright (C) 2020, Royler Anderson Said Ferreira et al. This is an open access article distributed under the Creative Commons Attribution License, which permits unrestricted use, distribution, and reproduction in any medium, provided the original work is properly cited.

Citation: Royler Anderson Said Ferreira, Bruno Pereira Gonçalves, Aline Mary Moreira de Melo, Jean Mark Lobo de Oliveira and David Barbosa de Alencarencar. "Pathological use of the internet causing social anxiety", International Journal of Development Research, 10, (06), 36970-36973.

\section{INTRODUCTION}

These people, more precisely young people, have outbreaks, crises, furious attacks, etc., the moment they become aware of the submission of connection, that is, when they are disconnected from the virtual world, they start to show dependence, starting to neglect himself and / or even with other people around him, being able to take his own life and that of other people who are also part of this group. And for that, in 2019, a study carried out by FundaçãoGetúlioVagas (FGV), proves that for $41 \%$ of young Brazilians, regarding the use of social networks, they show symptoms of depression, social anxiety or sadness [10], or that is, the Internet with a high frequency of use, whether in any segment, can be classified as abstinence or addiction. Thus, the concept of pathology is applied to strange behavior, that is, it is totally outside its standards or what has been normalized, where it can be defined by a person who is extremely happy or intelligent [1]. Within this concept, Pathology is linked to behavior, being crucial to the study of diseases and how they cause structural and / or mental stability. Taking into account these aspects, pathological dare of the internet, it was chosen as an object of study, because it is a current topic, which through its abusive use, brings an evil, Social Anxiety, as the main factor, being described from of self-reports by users who declare themselves as "internet addicts" or "internet addicts" (terms used by the users themselves), describing psychological aspects characterized by excessive concern in situations that require interaction with society.

\section{BIBLIOGRAPHIC REFERENCE}

Pathology: Pathology is the study (logos) of suffering (pathos). It analyzes the causes of diseases and associated changes at the level of cells, tissues and organs, which result in signs and symptoms present in the patient. There are two essential definitions found in the study of medicine and pathology: The Etiology is the source of the disease, which includes the root causes and the modifying factors. The Pathogenesis refers to the stages of development of the disease. It describes how fundamental factors start molecular and cellular changes that cause structural and functional irregularities that describe the disease. While the etiology exposes why the disease arises, the pathogenesis describes how the disease evolves [12]. In general it is linked to actions 
and mainly to the study of diseases and how they cause structural and/or mental changes. An abnormal action, that is totally out of your standards or what has been normalized can be defined by a person who is extremely happy or intelligent [1]. However, for this study the use of pathology will be entirely linked to the term disease, that is, the action of the sick use of something.

Participation of the Internet: Users suffer an overload of information or data, which can often be contradictory about some types of pathologies, which according to her are generated by the internet, emphasizing the extreme impacts that the media can cause with the pathological use of the Internet [6]. So, it is necessary to demonstrate how much the media and therefore the Internet, has one of the fundamental roles for the development of disorders, based on the data in this article to alarm how we are at the mercy of new pathologies that appear every day in our daily lives that are developed with the help of some type of technology connected to the internet.

Social Anxiety: To understand the Social Anxiety we must base it on its junction and its general division, that is, the understanding of Anxiety and Social. Social Anxiety, Social Phobia or Sociophobia, is an anxious syndrome characterized by the presence of behavioral alarm, nervous tension and discomfort triggered by exposure to social assessment - which occurs when the patient needs interaction among people, perform performances under monitoring or participate in social dynamics [11]. Anxiety can be present in a situation in which it presents real insecurity, in which it can be compare with a topic related to a psychic state, fear. It defines that its causes can be directly linked to conflicts, feelings of guilt and frustrations [2]. The Social term is entirely linked to the insertion of a being in a community, whether real or virtual. This insertion is linked to the individual having actions that avoid these scenarios in what involves some type of interaction or social situation [5]. As a study object among the related concepts, the virtual scenario will be chosen and given in a social media environment.

\section{MATERIALS AND METHODS}

Bibliographic searches in articles, magazines and websites, to understand pathology, social anxiety, social anxiety disorder and the internet. Quantitative research, using a form that was applied digitally on a free platform, in which it was posted on a social network and the respondents who will participate in this research were random. Descriptive research with support in matters, where they report subjects such as social anxiety, pathologies and the use of the internet. As a support, the free tool, GOOGLE FORMS, was used. This tool allows the creation of forms in order to enable the collection of responses quickly and effectively to carry out their analyzes. This artifice of data absorption may be present in the realization of obtaining materials referring to documentary research [4].

\section{RESULTS AND DISCURSIONS}

When examining some aspects, at least three most important ones found today are found as a basis. The first is the study of diseases that change structural and even mental aspects, Pathology. The second is a technology that appeared in the $90 \mathrm{~s}$, since then it has been evolving every day, which is the
Internet, with this evolution it is possible to cause psychological damage to society, this being the third aspect, Social Anxiety. The Pathology term is a branch of Medicine whose meaning is related to the "study of diseases", which derives from the Greek "pathos", which means "diseases" and "logos" which means "diseases". Despite the meaning, Pathology does not study all aspects of disease, but one of his main studies is that of abnormality in a person's structural behavior, whether it be a structural or mental change. The Internet is one of the most important tools of world communication today, it emerged in the late $60 \mathrm{~s}$ with the function of connecting research laboratories, and it was a guarantee of communication between scientist and military personnel not to break, even in a bombing situation. In the $90 \mathrm{~s}$, the world population got to know the Internet, and since then it has undergone a very rapid and vast evolution and even today it is still evolving. This evolution brought many advantages to society, where there was a huge leap in the exchange of information. As well as advantages, there were also disadvantages, one of which was the loss of psychological balance, which is a major current problem. Social Anxiety had its first concept in the mid-19th century, by the psychiatrist Henry Maudsley, who used another term, "melancholic panic". Social Anxiety or Sociophobia is understood to be the individual's personal insecurity, fear of being in public, nervousness at certain times in the midst of society, nervous tension, social discomfort, etc.

In view of the mentioned aspects, when interviewing some people it was possible to observe that when using the internet in a pathological way, it is presumed to analyze these factors and prove their connection in the contribution of the development of a serious risk disease to today's society, that is, the intensive use of the internet can alter personal psychological behavior based on self-reporting, causing Social Anxiety. From this self-report extracted from a questionnaire of 15 questions, in which 8 questions were considered most relevant in relation to the approach of this assertion, and applied at random, dealing with three aspects mentioned, Social Anxiety, Pathology and the Internet. In graphic 1 and 2, which correspond to questions 1 and 2, respectively, it is the knowledge about two determinant subjects, Pathology and Social Anxiety. The index was very significant where more than half of the people claim to have heard of Pathology and the rest never heard of it, as well as Social Anxiety which also showed the same index, that is, the knowledge of the respective subjects was very positive, this ends up in making them knowledgeable, which often leads us to make mistakes knowing, as the Brazilian website TecMundo [9] states.

Have you heard about Pathology?
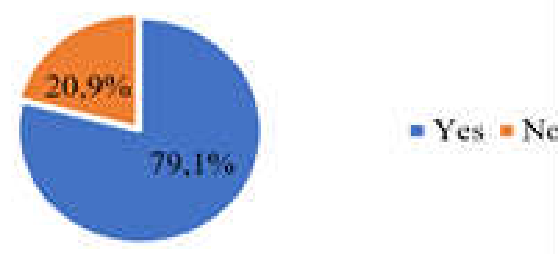

Source: Royler, 2020. 


\section{Have you heard about Social Anxiety?}

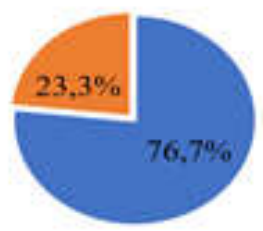

$=$ Yes $=$ No

Source: Royler, 2020.

Graph 2. Anxiety

According to graphic 3 which refers to question number 7 , exposed symptoms related to Social Phobia, according to the answers, was able to verify that most of the interviewees have already experienced one of the symptoms associated with Social Anxiety, however, they may or may not have been caused by some type of use. of social media through the technology present in our daily lives [7].

Fear. self-awareness and public embarrassment are linked to social anxiety, did you have or do you have any of them?

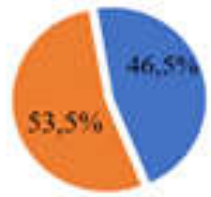

Source: Royler, 2020.

\section{Graph 3. Symptoms}

According to graphic 5 that represents question 14, the internet being treated as an "addiction", raised an interesting look, because as in question 4, the index of people who consider themselves addicted to the internet is relevant as those who are not addicted, with that we can take into consideration that the number of those who consider themselves to be intensive use is somewhat larger, so we can imagine the number of audiences in high proportions, in which this amount of positive responses could be increased drastically, and the American website itself [8], still reports the growth in $25 \%$ of internet users, a high value compared to the population in the United States.

Do you think you are subject to psychological behavioral damage due to the constant use of the internet?

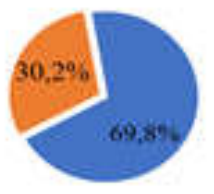

Source: Royler, 2020.

Graph 4. Damage
According to graphic 5 that represents question 14, the internet being treated as an "addiction", raised an interesting look, because as in question 4, the index of people who consider themselves addicted to the internet is relevant as those who are not addicted, with that we can take into consideration that the number of those who consider themselves to be intensive use is somewhat larger, so we can imagine the number of audiences in high proportions, in which this amount of positive responses could be increased drastically, and the American website itself [8], still reports the growth in $25 \%$ of internet users, a high value compared to the population in the United States.

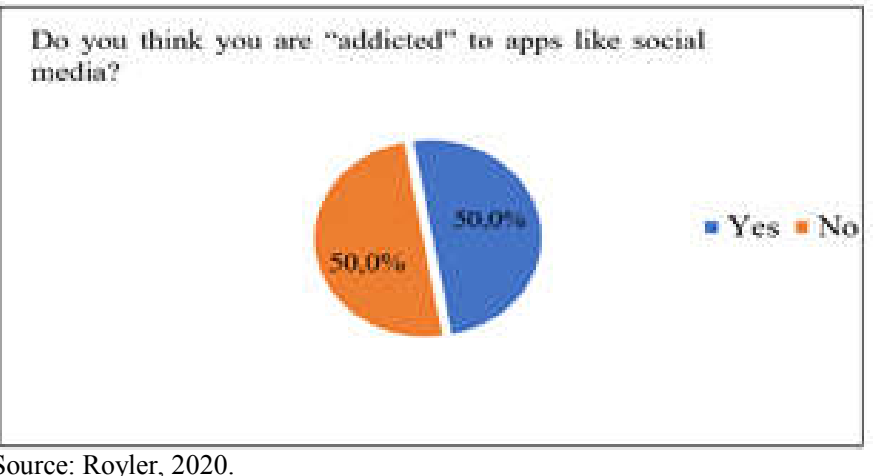

Graph 5. Addiction

Graphic 6 in accordance with the answers extracted in question 3 was almost unanimously positively, in relation to the daily use of the internet, because with the data obtained in this survey we can have as a basis how great the ease of access these days, so it is seen the large amount of people participating in this questionnaire who have daily access to the internet, which can be a negative fact to increase some indications of addictions, pathologies and so on.

Do you have direct access to the Internet?

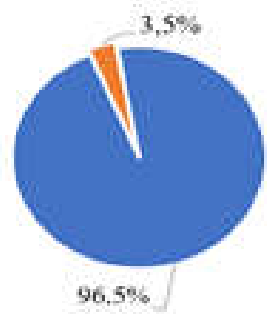

$=$ Yes $=$ No

Source: Royler, 2020.

\section{Graph 6. Internet}

According to graphic 7 corresponding to question 11 , it is notable that a large part of people don't even try to reduce the time they spend browsing, this is harmful and tends to get worse, as from that moment on, the person doesn't perceive such serious damage that can bring. In graphic 8 linked to question 9, it enters a delicate and complex subject where it deals with physical rest and metal, and it is worrying because most say they lose their sleep due to surfing the internet until very late. There is a study carried out by the psychiatrist in which he proves that almost $80 \%$ of young people check their social networks before going to sleep [13], and in view of this imbalance, other physical diseases are possible, for example to mention cardiovascular problems. 
Do you try to reduce the amount of time you spend on the internet and can't?

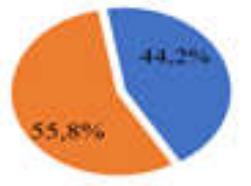

Source: Royler, 2020.

\section{Graph 7. Time}

Do you lose sleep because you are surfing the Internet until very late at night?

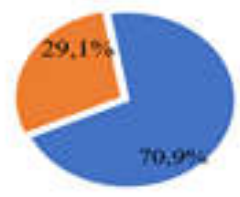

Source: Royler, 2020.

\section{Graph 8. Loss}

\section{Conclusion}

The situation of internet dependence, showing the degree of pathology in relation to the abusive or excessive use of this technology. A possible solution to this problem that is a high level and could even be called a 21 st century disease, would be to warn users who are already addicted, or rather, dependent, of how much they are sunk in this world that damages their personal life, work and even family, which perhaps family life is one of the most affected, as well as the people around them.

Acknowledgements: I first thank God, who is the author of life and owner of all wisdom, who has always been with me throughout my academic journey. My family, who always supported the realization of this dream, especially my parents, Amilton da Silva and Adaid Menezes, my uncles Luiz Ferreira, Amud Said and Sostenes Menezes and the teachers in particular Msc. Bruno Gonçalves, who shared their knowledge providing to achieve this dream. My thanks.

\section{REFERENCES}

ATKINSON. Rita L. et al. Introduction to Hilgard's psychology. 13 ed. Porto Alegre: EditoraAritmed, 2002.

BRAGHIROLLI, E. et al. General psychology.35ed. Rio de Janeiro: Editora Vozes, 2014.

CARBONELL, X. et al. A bibliometric analysis of the scientific literature on Internet, video games, and cell phone addiction. United States: EditoraJournalofThe Medical Library Association, 2009. Available at: https:/www.ncbi.nlm.nih.gov/pmc/articles/PMC2670219/ . Accessed on: 03 feb. 2020.

Gil, A. How to develop research projects. 4. ed. São Paulo: Editora Atlas, 2002.

How far have we come? Young man tries to poison mother by collecting his smartphone. Available at: https://www.tecmundo.com.br/polemica/76956/pontochegamos-jovem-tenta-envenenar-mae-recolhsmartphone.htm. Accessed on: 07 feb. 2020.

Internet addiction disorder. Available at: http://www. minddisorders.com/Flu-Inv/Internet-addictiondisorder.html. Accessed on: 07 feb. 2020.

KUMAR, V. et al. Basic Pathology. 9 ed. Rio de Janeiro: Editora Elsevier, 2013.

NICOLACI-DA-COSTA, A. Internet: the negativity of media discourse versus the positivity of personal experience. Which to give credit to ?. São Paulo: SciELO, 2002. Available at: http://www.scielo.br/ scielo.php?pid=S 1413294X2002000100004\&script=sci_abstract\&tlng=pt. Accessed on: 04 feb. 2020 Psychology Studies.

Social networks generate anxiety and depression in young Brazilians, says study. Available at: https://www. techtudo.com.br/noticias/2019/10/redes-sociaisgeramansiedade-e-depressao-em-jovens-brasileiros-dizestudo.html. Accessed on: 08 fev. 2020.

Technology addiction requires treatment with therapy and medication. Available at: http://g1.globo.com/ globonews/ noticia/2015/09/vicio-em-tecnologia-requer-tratamentocom-terapia-e-remedios.html. Accessed on: 14 fev. 2020.

The ten diseases that most affect the world. Available at: https://casule.com/as-10-doencas-psicologicas-que-maisafetam-o-mundo/. Accessed on 12 feb. 2020.

Victims of digital addiction. Available at: https: //istoe.com.br/326665_VITIMAS+DA+DEPENDENCIA +DIGITAL/. Accessed on: 07 feb. 2020.

VOLPATO, A. et al. Diagnostic and statistical manual of mental disorders. Porto Alegre: EditoraArtmed, 2014. 